CORIGINAL ARTICLE

Volume 15 Issue 12020

DOI: 10.21315/aos2020.15.1.427

ARTICLE INFO

Submitted: $20 / 02 / 2020$

Accepted: 29/06/2020

Online: $15 / 07 / 2020$

\section{Antibacterial Property of Synsepalum dulcificum Leaves Aqueous Extract against Oral Pathogens and its Chemical Compounds}

\author{
Hanim Afzan Ibrahim ${ }^{\mathrm{a}, \mathrm{b}}$, Nur Karyatee Kassima, ${ }^{\mathrm{a}, \mathrm{b}}$, Noor Azlin Azraini \\ Che Soh ${ }^{\mathrm{b}}$, Zulkhairi Othmanc, Tuan Nadrah Naim Tuan Ismaila ${ }^{*}$ \\ ${ }^{a}$ School of Dental Sciences, Universiti Sains Malaysia, \\ 16150 Kubang Kerian, Kelantan, Malaysia \\ ${ }^{b}$ Department of Chemical Pathology, School of Medical Sciences, \\ Universiti Sains Malaysia, 16150 Kubang Kerian, Kelantan, Malaysia \\ 'School of Health Sciences, Universiti Sains Malaysia, \\ 16150 Kubang Kerian, Kelantan, Malaysia \\ ${ }^{*}$ Corresponding author: tnadrah@usm.my
}

To cite this article: Ibrahim HA, Kassim NK, Che Soh NAA, Othman Z, Tuan Ismail TNN (2020). Antibacterial property of Synsepalum dulcificum leaves aqueous extract against oral pathogens and its chemical compounds. Arch Orofac Sci, 15(1): 55-64. https://doi.org/10.21315/aos2020.15.1.427

To link to this article: https://doi.org/10.21315/aos2020.15.1.427

\begin{abstract}
Synsepalum dulcificum (S. dulcificum) commonly known as "miracle fruit" because its berries have the capability to modify sour taste to the sweet taste when eaten. Beside the berries, $S$. dulcificum leaves were also known to possess biological properties such as antioxidant, antimutagenic and antidiabetic activities. However, the study of its antimicrobial activity against oral pathogen is still lacking. Thus, this study aimed to evaluate the antibacterial activity of its leaves against cariogenic bacteria and to analyse its phytochemical compounds. The samples of $S$. dulcificum leaves were collected in Kelantan, the east coast region of Peninsular Malaysia and extracted with distilled water using a Soxhlet technique. The antibacterial activity of the $S$. dulcificum leaves aqueous extract against Streptococcus mutans (S. mutans), Streptococcus sobrinus ( $S$. sobrinus) and Lactobacillus salivarius ( $L$. salivarius) was evaluated using the broth microdilution assay. The identification of the phytochemical compounds was performed using gas chromatography-mass spectrometry (GC-MS). The antibacterial study showed the minimum inhibitory concentration of $S$. dulcificum leaves aqueous extract against $S$. mutans and $S$. sobrinus were $16 \mathrm{mg} / \mathrm{mL}$ and $8 \mathrm{mg} / \mathrm{mL}$, respectively. Interestingly, there was no inhibitory effect of $S$. dulcificum leaves aqueous extract against $L$. salivarius. A total of 42 chemical compounds were identified and major identified bioactive compounds groups were heterocyclic and phenolic compounds. Our results suggested $S$. dulcificum leaves aqueous extract has antimicrobial properties against $S$. mutans and $S$. sobrinus, but no inhibitory activity against oral normal flora, with the presence of bioactive compounds has potential in oral care products application.
\end{abstract}

Keywords: Synsepalum dulcificum leaves, antimicrobial activity, oral pathogens, gas chromatography mass spectrometry, broth microdilution assay 


\section{INTRODUCTION}

Synsepalum dulcificum ( $S$. dulcificum) is a shrub native to tropical West Africa. It is called miracle fruit due to its berry's ability to cause sour foods to taste sweet. It was reported that the glycoprotein (miraculin) is the active compound that works by altering the sweet receptor (Koizumi et al., 2011). There were few studies of chemical compounds of its berries that obtained from regions such as Malaysia ( $\mathrm{He}$ et al., 2016) and China (Du et al., 2014). The results revealed that all samples were rich in phenolic contents and had antioxidant properties.

However, the benefit of $S$. dulcificum is not limited to its berries only. In Malaysia, its leaves were traditionally used to treat toothache by chewing the leaves. Previous studies of $S$. dulcificum leaves had revealed the presence of antioxidant, antimutagenic, antidiabetic and antimicrobial properties in this plant. Study of methanol extract of its leaves grown from Nigeria showed that the extract was rich in phenolic contents and had antioxidant activity (Obafemi et al., 2017b) as well as has potential as antidiabetic agent (Obafemi et al., 2017a). On the other hand, $S$. dulcificum leaves aqueous extract collected in Taiwan showed that the extract was also rich in phenolic contents and exhibited antimutagenic and anti-oxidative damage activities (Chen et al., 2015). However, there were various types of phenolic compounds identified in both studies. Methanol extract of $S$. dulcificum leaves collected in Nigeria has that gallic acid, chlorogenic acid, caffeic acid, ellagic acid, catechin, epicatechin, quercetin, quercitrin, isoquercitrin, rutin and kaempferol as the identified phenolic compounds (Obafemi et al., 2017a). While study of water extract of $S$. dulcificum leaves collected in Taiwan has p-hydroxybenzoic acid, vanillic acid, syringic acid, transp-coumaric acid and veratric acid as the identified phenolic compounds (Chen et al., 2015). These results showed that the method of extraction and cultivation area could be the factors that contributed to the discrepancies.

A previous study of methanol and ethanol extracts of $S$. dulcificum leaves found that both extracts possessed antibacterial activity against facultative anaerobic bacterium Listeria monocytogenes (Wasoh et al., 2017). The study of antibacterial activity of $S$. dulcificum leaves is still lacking. To date, no other antibacterial study of $S$. dulcificum leaves has been investigated except study by Wasoh et al. (2017). Thus, our focused in the current study was to evaluate the antibacterial activity of $S$. dulcificum leaves against oral pathogens which are Streptococcus mutans (S. mutans) and Streptococcus sobrinus (S. sobrinus). Its inhibitory effect against oral normal flora which is Lactobacillus salivarius (L. salivarius) was also evaluated. $S$. mutans is a facultative anaerobic bacterium that is associated with the development of dental caries. The acid producing $S$. mutans dissolved tooth structure in the presence of carbohydrate (Guo et al., 2013). The second harmful oral pathogen that related to the development of tooth cavities is S. sobrinus (Damle, 2018). On the other hand, L. salivarius is a probiotic that has beneficial effects in the oral cavity by inhibiting cariogenic streptococci and candida (Meurman, 2005). Thus, the best antibacterial agent should have antibacterial activity against oral pathogens but not against oral probiotic.

An antimicrobial agent such as chlorhexidine has been reported to prevent dental carries effectively. However, a recent study showed that long term use of chlorhexidine in oral care product is potentially causing multidrugresistant (Saleem et al., 2016). The use of the natural product can contribute as the alternative to the synthetic chemical substance for caries prevention. Hence, in the present study, the antibacterial property of $S$. dulcificum leaves aqueous extract was evaluated. Water extract is preferred since alcohol is well-known to cause dryness to the oral mucosa. The use 
of water is needed, especially for oral care products (McCullough and Farah, 2008). Its phytochemical compounds were also analysed since the region of plantation might contribute to the phytochemical discrepancy. The previous studies of methanol extract of $S$. dulcificum leaves collected from two countries showed that the chemical compounds were different (Chen et al., 2010; Obafemi et al., 2017b). In the present study, the chemical compounds of $S$. dulcificum leaves was analysed by gas chromatographymass spectrometry (GC-MS) because this technique is highly sensitive, fast and no standards are needed since the identification of the chemical compounds was carried out by comparing the mass spectra with the libraries (Hübschmann, 2015).

\section{MATERIALS AND METHODS}

\section{Sample of S. dulcificum}

S. dulcificum was collected from Kota Bharu, Kelantan. The plant was confirmed by botanist, Dr. Mohd Firdaus Ismail from Institute of Bioscience, University Putra Malaysia and the voucher specimen was deposited at the Herbarium of Institute of Bioscience, University Putra Malaysia. The voucher specimen number was SK 3263/17.

\section{Preparation of S. dulcificum Leaves Aqueous Extract}

S. dulcificum leaves aqueous extract was prepared using Soxhlet extraction method. The $S$. dulcificum leaves were harvested and cleaned first with tap water and rinsed twice in sterile distilled water (Seong et al., 2018). The leaves were then dried at $37^{\circ} \mathrm{C}$ in the oven and ground into powder. The $S$. dulcificum leaves were extracted with distilled water using a Soxhlet apparatus, and the resulting water extract was freeze-dried to obtain crude water extract (Ranasinghe et al., 2012). The dried extract was kept at $-20^{\circ} \mathrm{C}$.

\section{Antimicrobial Activity}

In the current study, $S$. mutans (ATCC 25175) and S. sobrinus (ATCC33478) were obtained from the American Type Culture Collection, USA and purchased from Oxoid Ltd., UK. L. salivarius (clinical isolate) was obtained from the Craniofacial Laboratory, School of Dental Sciences, Universiti Sains Malaysia, Kelantan, Malaysia. The Mueller Hinton Blood Agar (MHBA) and Brain Heart Infusion (BHI) medium were purchased from Oxoid Ltd., UK.

\section{Preparation of the Bacterial Suspension}

$S$. mutans, S. sobrinus and $L$. salivarius were cultured on MHBA and were incubated at $37^{\circ} \mathrm{C}$ for $48 \mathrm{~h}$ under an anaerobic condition. After incubation, the colonies were suspended in $1 \mathrm{~mL}$ of peptone water and were standardised to $0.5 \mathrm{McF}$ arland $\left(1 \times 10^{8}\right.$ $\mathrm{CFU} / \mathrm{mL}$ ) by using a nephelometer (Balto et al., 2017).

\section{Determination of Minimum Inhibitory Concentrations (MIC)}

The MIC of $S$. dulcificum leaves extract against tested oral bacteria was determined by broth microdilution method with some modifications (Balto et al., 2017). A crude extract of dry $S$. dulcificum leaves was dissolved in distilled water at a concentration of $32 \mathrm{mg} / \mathrm{mL}$. Two-fold serial dilutions with BHI medium in a sterile 96-well microtiter plates were performed. Final concentrations of $S$. dulcificum leaves extract ranged from $0.25 \mathrm{mg} / \mathrm{mL}$ to $32 \mathrm{mg} / \mathrm{mL}$. Each plate had a set of controls: a column with the chlorhexidine $(0.12 \%)$ as the positive control, a column with all solutions with the exception of the $S$. dulcificum leaves extract as a negative control and a column with all solutions with the exception of the bacterial suspension as a sterility control. Each well, except for the sterility control, was inoculated with $20 \mu \mathrm{l}$ of bacterial suspension $\left(1 \times 10^{6}\right.$ $\mathrm{CFU} / \mathrm{mL}$ ). The plates containing tested oral 
bacteria were incubated at $37^{\circ} \mathrm{C}$ for $48 \mathrm{~h}$ under anaerobic condition. After incubation, each well was added with $10 \mu \mathrm{l}$ of resazurin (Sigma Aldrich, US) $(0.01 \%)$ indicator solution and was incubated for $2 \mathrm{~h}$ at $37^{\circ} \mathrm{C}$ under anaerobic condition. After two hours, the lowest concentration at which colour change to pink occurred was taken as the MIC value. This experiment was done in triplicate independently. Resazurin is a blue non-fluorescent and non-toxic dye that becomes pink and fluorescent when reduced to resorufin by oxidoreductases within viable cells (Adan et al., 2016).

\section{GC-MS Conditions and Parameters}

The chemical compounds of $S$. dulcificum leaves aqueous extract was analysed by GC-MS system operating on electron impact ionisation (EI) mode fixed at $70 \mathrm{eV}$ on Hewlett Packard 6890 Gas Chromatograph coupled to 5973N Mass Selective Detector (Agilent Technologies, USA) equipped with fused silica capillary column, HP-5 $30 \mathrm{~m}$ length $\times 0.25 \mathrm{~mm}$ internal diameter $\times 0.25 \mu \mathrm{m}$ film thickness. Helium was used as carrier gas with flow rate $1.0 \mathrm{~mL} / \mathrm{min}$. The initial temperature of the column was programmed from $50^{\circ} \mathrm{C}$ (held for $2 \mathrm{~min}$ ) and then was heated to $280^{\circ} \mathrm{C}$ (held for $10 \mathrm{~min}$ ) with a $20^{\circ} \mathrm{C} / \mathrm{min}$ rate. The injection and interface temperatures were set at $250^{\circ} \mathrm{C}$ and $280^{\circ} \mathrm{C}$, respectively.
The sample $(1 \mu \mathrm{l})$ injected in splitless mode and analysed in MS full scan mode; range $m / z$ 40-650. Acquisition of data was performed using Chemsation software. The sample was derivatised by addition of MSTFA (N-methyl-N-trimethylsilyltrifluoroacetamide) prior to the analysis to make the compounds more volatile and thus amenable for GC analysis.

\section{Identification of Chemical Compounds}

The $S$. dulcificum compounds were identified by comparing their mass spectra with National Institute of Standards and Technology (NIST02) and Wiley275 libraries $(\geq 80 \%$ matching). The percentage compound was calculated from the summation of the peak areas of $S$. dulcificum compounds.

\section{RESULTS}

The antimicrobial activity of $S$. dulcificum leaves aqueous extract is shown in Table 1. $S$. dulcificum leaves aqueous extract showed inhibitory activity against $S$. mutans and $S$. sobrinus with MIC value of $16 \mathrm{mg} / \mathrm{mL}$ and $8 \mathrm{mg} / \mathrm{mL}$; respectively. Interestingly, there was no inhibitory activity of aqueous extract of $S$. dulcificum leaves against $L$. salivarius at a concentration at least $32 \mathrm{mg} / \mathrm{mL}$. The lowest concentration at which colour change to pink occurred was taken as the MIC value.

Table 1: Antibacterial activity of Synsepalum dulcificum leaves aqueous extract against oral pathogens

\begin{tabular}{|c|c|c|c|c|c|c|}
\hline \multirow[b]{2}{*}{ Microorganism } & \multicolumn{4}{|c|}{ Inhibitory effect } & \multirow[b]{2}{*}{$\begin{array}{c}\text { Positive } \\
\text { control } \\
\left(0.12 \% \mathrm{CHX}^{*}\right)\end{array}$} & \multirow[b]{2}{*}{$\begin{array}{l}\text { Negative } \\
\text { control } \\
\text { (Brain Heart } \\
\text { Infusion) }\end{array}$} \\
\hline & $\begin{array}{l}32 \mathrm{mg} / \mathrm{mL} \text { of } \\
\text { S. dulcificum } \\
\text { leaves } \\
\text { aqueous } \\
\text { extract }\end{array}$ & $\begin{array}{l}16 \mathrm{mg} / \mathrm{mL} \text { of } \\
\text { S. dulcificum } \\
\text { leaves } \\
\text { aqueous } \\
\text { extract }\end{array}$ & $\begin{array}{l}8 \mathrm{mg} / \mathrm{mL} \text { of } \\
\text { S. dulcificum } \\
\text { leaves } \\
\text { aqueous } \\
\text { extract }\end{array}$ & $\begin{array}{l}4 \mathrm{mg} / \mathrm{mL} \text { of } \\
\text { S. dulcificum } \\
\text { leaves } \\
\text { aqueous } \\
\text { extract }\end{array}$ & & \\
\hline $\begin{array}{l}\text { Streptococcus } \\
\text { mutans }\end{array}$ & + & + & - & - & + & - \\
\hline $\begin{array}{l}\text { Streptococcus } \\
\text { sobrinus }\end{array}$ & + & + & + & - & + & - \\
\hline $\begin{array}{l}\text { Lactobacillus } \\
\text { salivarius }\end{array}$ & - & - & - & - & + & - \\
\hline
\end{tabular}


The result of GC-MS analysis of water extract of $S$. dulcificum leaves is shown in Table 2. A total of 42 chemical compounds were identified and the major identified compounds were $\mathrm{N}$-furfuryl pyrrole $(5.45 \%)$, 2-Furancarboxaldehyde, 5-(hydroxymethyl)(5.28\%), 4H-Pyran-4-one, 2,3-dihydro3,5-dihydroxy-6-methyl- (4.31\%) and 2,3-Dihydro-5-hydroxy-6-methyl-4H-pyran4 -one $(4.22 \%)$.

The chemical compounds were categorised into few groups, which were heterocyclic compounds, phenolic compounds, terpenoids and steroid. The heterocyclic compounds were the main identified group and contributed to the $15.98 \%$. The main identified heterocyclic compounds include $\mathrm{N}$-furfuryl pyrrole (5.45\%), 2-Furancarboxaldehyde and 5-(hydroxymethyl)- (5.28\%). The phenolic compounds were the second main identified group and contribute to $8.15 \%$. The main identified phenolic compounds were 4-vinyl-phenol (2.31\%) and 2-Methoxy-4vinylphenol $(1.83 \%)$.

Table 2: Chemical compounds of Synsepalum dulcificum leaves aqueous extract

No Retention time (min) \% of total Compounds name $\quad \%$ Library matching

\begin{tabular}{|c|c|c|c|c|}
\hline & & & Heterocyclic compounds & \\
\hline 1. & 4.700 & $0.75 \%$ & Furfural & 96 \\
\hline 2. & 5.450 & $1.14 \%$ & 2-Furanmethanol & 99 \\
\hline 3. & 5.891 & $0.13 \%$ & 5-Methylene-2(5H)14-furanone & 91 \\
\hline 4. & 6.521 & $0.83 \%$ & 2(3H)-Furanone, dihydro- & 91 \\
\hline 5. & 6.409 & $0.11 \%$ & Ethanone,1-(2-furanyl)- & 87 \\
\hline 6. & 6.850 & $0.12 \%$ & 2(3H)-Furanone, 5-methyl- & 83 \\
\hline 7. & 6.899 & $0.16 \%$ & 2,5-Furandione, 3-methyl- & 90 \\
\hline 8. & 6.948 & $0.23 \%$ & 2,5-Dimethyl-3(2H)Furanone & 80 \\
\hline 9. & 7.158 & $1.27 \%$ & 5-methyl furfural & 96 \\
\hline 10. & 7.326 & $0.51 \%$ & 2,4-Dihydroxy-2,5-dimethyl-3(2H)-furan-3-one & 91 \\
\hline 11. & 9.147 & $5.45 \%$ & $\mathrm{~N}$-furfuryl pyrrole & 90 \\
\hline \multirow[t]{2}{*}{12.} & 9.693 & $5.28 \%$ & 2-Furancarboxaldehyde, 5-(hydroxymethyl)- & 83 \\
\hline & & & Phenolic & \\
\hline 13. & 7.396 & $0.53 \%$ & Phenol & 94 \\
\hline 14. & 9.399 & $2.31 \%$ & 4-vinyl-phenol & 87 \\
\hline 15. & 10.008 & $1.83 \%$ & 2-Methoxy-4-vinylphenol & 98 \\
\hline 16. & 10.225 & $1.57 \%$ & Phenol,2,6-dimethoxy- & 97 \\
\hline 17. & 10.764 & $0.89 \%$ & Phenol,2-methoxy-4-(1-propenyl)- & 95 \\
\hline \multirow[t]{2}{*}{18.} & 11.975 & $1.02 \%$ & Phenol,2,6-dimethoxy-4-(2-propenyl)p & 91 \\
\hline & & & Terpenoids & \\
\hline 19. & 16.086 & $0.07 \%$ & Squalene & 91 \\
\hline 20. & 20.441 & $0.27 \%$ & 3-beta-o-cinnamoyl-lupeol & 86 \\
\hline 21. & 21.022 & $0.09 \%$ & Norolean-12-ene & 91 \\
\hline 22. & 21.575 & $0.35 \%$ & Lup-20(29)-en-3-ol, acetate, (3.beta.) & 94 \\
\hline
\end{tabular}


Table 2 (Continued)

\begin{tabular}{|c|c|c|c|c|}
\hline No & Retention time (min) & $\%$ of total & Compounds name & $\%$ Library matching \\
\hline & & & Steroids & \\
\hline \multirow[t]{2}{*}{23.} & 19.482 & $0.12 \%$ & Chondrillasterol & 95 \\
\hline & & & Others & \\
\hline 24. & 2.817 & $3.70 \%$ & Acetic acid & 90 \\
\hline 25. & 5.695 & $0.23 \%$ & Acetol acetate & 90 \\
\hline 26. & 5.982 & $0.56 \%$ & 1,3-Cyclopentenedione & 95 \\
\hline 27. & 6.311 & $0.61 \%$ & 1-Hydroxy-3-penten-2-one & 86 \\
\hline 28. & 6.675 & $0.81 \%$ & 2-Hydroxy-2cyclopenten-1-one & 91 \\
\hline 29. & 7.487 & $0.48 \%$ & Pyrazine & 86 \\
\hline 30. & 7.718 & $0.27 \%$ & Cycloheptatriene & 90 \\
\hline 31. & 7.788 & $0.98 \%$ & Pyrimidine & 86 \\
\hline 32. & 7.886 & $0.53 \%$ & 2-Cyclopenten-1-one, 2-hydroxy-3-methyl- & 94 \\
\hline 33. & 8.418 & $4.22 \%$ & $\begin{array}{l}\text { 2,3-Dihydro-5-hydroxy-6-methyl-4H-pyran-4- } \\
\text { one }\end{array}$ & 90 \\
\hline 34. & 8.524 & $4.31 \%$ & $\begin{array}{l}\text { 4H-Pyran-4-one, 2,3-dihydro-3,5-dihydroxy-6- } \\
\text { methyl- }\end{array}$ & 80 \\
\hline 35. & 8.573 & $0.94 \%$ & Cyclopentene & 81 \\
\hline 36. & 11.450 & $2.16 \%$ & Megastigmatrienone & 96 \\
\hline 37. & 11.821 & $1.97 \%$ & Dihydro-coniferyl alcohol & 90 \\
\hline 38. & 12.165 & $0.51 \%$ & Myristic acid & 96 \\
\hline 39. & 15.581 & $0.05 \%$ & 9,17-Octadecadienal & 95 \\
\hline 40. & 15.911 & $0.02 \%$ & 9-Octadecenamide & 87 \\
\hline 41. & 17.808 & $0.08 \%$ & Vitamin $\mathrm{E}$ & 99 \\
\hline
\end{tabular}

The other groups that were identified in the present study were terpenoids and steroid. Terpenoids and steroid were identified in a small percentage which contributes to the $0.78 \%$ and $0.12 \%$, respectively. The main identified terpenoids were lu-20(29)-en3-ol,acetate, 3(beta) (0.35\%), 3.beta.-Ocinnamoyl-lupeol $(0.27 \%)$.

\section{DISCUSSION}

Our study showed that water extract of $S$. dulcificum leaves had antibacterial activity against $S$. mutans and $S$. sobrinus. However, no inhibitory activity of water extract of $S$. dulcificum leaves against $L$. salivarius. The antibacterial activity of $S$. dulcificum leaves against oral pathogens was studied here for the first time. A previous study found that both ethanol and methanol extracts of S. dulcificum leaves had antibacterial activities against Listeria monocytogenes (Wasoh et al., 2017). In the present study, water extract was used as an alternative to solvent extract as it is a universal solvent used for natural product extraction and has been widely used among traditional healers to extract various medicinal plants (Balakrishnan et al., 2014). Furthermore, water-based is the best formulation for oral mucosa compared to alcohol based because of its potential increase in cancer risk (Lachenmeier, 2012). Water is also cost-effective and more favourable when compared to other solvents since it is non-toxic and can be easily absorbed. Likewise, some bio-active compounds such as phenolic compounds are water soluble (Saltveit, 2017). 
In the present study, the chemical compounds were categorised into few groups and heterocyclic compounds were the main identified group. This was the first time the heterocyclic compounds were found as major compounds. Method of chemical compounds analysis could be the factor that contributed to this discrepancy. Since heterocyclic compounds were volatile compounds, they were amenable to the GCMS analysis. The main identified compounds include $\mathrm{N}$-furfuryl pyrrole $(5.45 \%)$, 2-Furancarboxaldehyde, 5-(hydroxymethyl)(5.28\%), 4H-Pyran-4-one, 2,3-dihydro3,5-dihydroxy-6-methyl- (4.31\%) and 2,3-Dihydro-5-hydroxy-6-methyl-4H-pyran4 -one $(4.22 \%)$ were found for the first time from this plant. A previous study showed 2-furancarboxaldehyde, 5-(hydroxymethyl) has antimicrobial activity against both gram positive and negative bacterial as well as fungi (Mohammed, 2013).

The phenolic compounds were the second main identified group and contributed to $8.15 \%$. Similar finding was observed in $S$. dulcificum leaves that obtained from Nigeria (Obafemi et al., 2017b). However, study by Obafemi et al. (2017b) found that none of the identified phenolic compounds were the same. This study used methanol as a solvent and the extract was analysed by high-performance liquid chromatography. The method of extraction (Azmir et al., 2013) and analysis technique (Koparde et al., 2017) could be the factors that influenced the chemical compounds in the $S$. dulcificum leaves. In the current study, the main identified phenolic compounds were 4-vinyl-phenol (2.31\%) and 2-methoxy-4vinylphenol (1.83\%). Phenolic compounds were documented to possess antibacterial effect by disrupting the bacterial lipid-protein interface due to its ability to acts as nonionic surface-active agent (Greenberg et al., 2008).
The other groups identified in the present study were terpenoids and steroid. Terpenoids and steroid were identified in a small percentage which contributed to the $0.78 \%$ and $0.12 \%$, respectively. The main identified terpenoids were lu-20(29)-en3-ol,acetate, 3(beta) (0.35\%), 3.beta.-Ocinnamoyl-lupeol $(0.27 \%)$. The previous study of GC-MS analysis of methanol extract of $S$. dulcificum leaves obtained in Taiwan showed that none of the terpenoids were similar (Ragasa et al., 2015). Terpenoids are well-known to possess antibacterial activity (Ludwiczuk et al., 2017). The antibacterial mode of action of terpenoids could be due to their ability to inhibit oxygen uptake and oxidative phosphorylation which are crucial processes for microbial survival (Griffin et al., 1999).

Although steroid was identified in small percentage, this compound was not identified in methanol extract of $S$. dulcificum leaves obtained in Nigeria (Obafemi et al., 2017b). On the other hand, methanol extract of $S$. dulcificum leaves collected in Taiwan showed the presence of steroids such as $\beta$-sitosterol and stigmasterol (Chen et al., 2010). This finding showed that the cultivation area might influence the chemical compounds of the $S$. dulcificum. The only steroid identified in the present study was chondrillasterol $(0.12 \%)$. A recent study of chondrillasterol showed that this compound has the antibacterial property against Staphylococcus aureus, Klebsiella pneumoniae and Pseudomonas aeruginosa (Mozirandi et al., 2019).

\section{CONCLUSION}

The aqueous extract of $S$. dulcificum leaves against $S$. mutans and $S$. sobrinus, the cariogenic bacteria revealed the promising result, suggesting its potential application in the oral care product. Further cytotoxicity test of its aqueous extract on gingival human cell and preclinical testing is needed to promote application of crude extract of $S$. dulcificum in the oral health care industry. 


\section{ACKNOWLEDGEMENTS}

The authors wish to thank Mr. Mohamad Ezany Yusoff from Craniofacial Science Laboratory, School of Dental Sciences, Universiti Sains Malaysia for his technical assistance in antimicrobial testing. The authors would like to thank Universiti Sains Malaysia for providing financial support under Short Term Grant, (304/ PPSG/61313196).

\section{REFERENCES}

Adan A, Kiraz Y, Baran Y (2016). Cell proliferation and cytotoxicity assays. Curr Pharm Biotechnol, 17(14): 1213-1221. https://doi.org/10.2174/138920101766616 0808160513

Azmir J, Zaidul ISM, Rahman MM, Sharif KM, Mohamed A, Sahena F et al. (2013). Techniques for extraction of bioactive compounds from plant materials: A review. f Food Eng, 117(4): 426-436. https://doi .org/10.1016/j.jfoodeng.2013.01.014

Balakrishnan B, Paramasivam S, Arulkumar A (2014). Evaluation of the lemongrass plant (Cymbopogon citratus) extracted in different solvents for antioxidant and antibacterial activity against human pathogens. Asian Pac $\mathcal{f}$ Trop Dis, 4(Suppl 1): S134-S139. https://doi.org/10 .1016/S2222-1808(14)60428-X

Balto H, Al-Sanie I, Al-Beshri S, Aldrees A (2017). Effectiveness of Salvadora persica extracts against common oral pathogens. Saudi Dent F, 29(1): 1-6. https://doi.org/10 $.1016 / j . s d e n t j .2016 .11 .001$

Chen CY, Wang YD, Wang HM (2010). Chemical constituents from the leaves of Synsepalum dulcificum. Chem Nat Compd, 46(3): 495. https://doi.org/10.1007/s 10600 $-010-9658-6$
Chen TY, Kang ZC, Yen MT, Huang MH, Wang BS (2015). Inhibitory effect of aqueous extracts from Miracle Fruit leaves on mutation and oxidative damage. Food Chem, 169: 411-416. https://doi.org/10 $.1016 /$ j.foodchem.2014.08.022

Damle SG (2018). Competence and transformation of oral Streptococcus sobrinus in dental caries. Contemp Clin Dent, 9(Suppl 2): S195-S196. https://doi.org/10 .4103/ccd.ccd_689_18

Du L, Shen Y, Zhang X, Prinyawiwatkul W, Xu Z (2014). Antioxidant-rich phytochemicals in miracle berry (Synsepalum dulcificum) and antioxidant activity of its extracts. Food Chem, 153: 279-284. https://doi .org/10.1016/j.foodchem.2013.12.072

Greenberg M, Dodds M, Tian M (2008). Naturally occurring phenolic antibacterial compounds show effectiveness against oral bacteria by a quantitative structureActivity relationship study. I Agric Food Chem, 56(23): 11151-11156. https://doi .org/10.1021/jf8020859

Griffin SG, Wyllie SG, Markham JL, Leach DN (1999). The role of structure and molecular properties of terpenoids in determining their antimicrobial activity. Flavour Frag f, 14(5): 322-332. https://doi.org/10.1002/(SICI) 1099 $-1026(199909 / 10) 14: 5<322:$ :AID -FFJ837>3.0.CO;2-4

Guo L, Hu W, He X, Lux R, McLean J, Shi W (2013). Investigating acid production by Streptococcus mutans with a surfacedisplayed $\mathrm{pH}$-sensitive green fluorescent protein. PLOS ONE, 8(2): e57182. https:// doi.org/10.1371/journal.pone.0057182

He Z, Tan JS, Abbasiliasi S, Lai OM, Tam YJ, Ariff AB (2016). Phytochemicals, nutritionals and antioxidant properties of miracle fruit Synsepalum dulcificum. Ind Crops Prod, 86: 87-94. https://doi .org/10.1016/j.indcrop.2016.03.032 
Hübschmann HJ (2015). Handbook of GC-MS: Fundamentals and Applications, 3rd edn. New York: John Wiley \& Sons.

Koizumi A, Tsuchiya A, Nakajima KI, Ito K, Terada T, Shimizu-Ibuka A et al. (2011). Human sweet taste receptor mediates acidinduced sweetness of miraculin. Proc Natl Acad Sci U S A, 108(40): 16819-16824. https://doi.org/10.1073/pnas.1016644108

Koparde AA, Magdum CS, Doijad RC (2017). Phyto active compounds from herbal plants extracts: Its extraction, isolation and characterization. World f Pharm Res, 6(8): 1186-1205.

Lachenmeier DW (2012). Alcohol-containing mouthwash and oral cancer-Can epidemiology prove the absence of risk? Ann Agric Environ Med, 19(3): 609-613.

Ludwiczuk A, Skalicka-Woźniak K, Georgiev MI (2017). Terpenoids. In: Badal S, Delgoda R (eds.), Pharmacognosy: Fundamentals, Applications and Strategies. Amsterdam: Elsevier Inc., pp. 233-266. https://doi. org/10.1016/C2014-0-01794-7

McCullough MJ, Farah CS (2008). The role of alcohol in oral carcinogenesis with particular reference to alcohol-containing mouthwashes. Aust Dent F, 53(4): 302305. https://doi.org/10.1111/j.1834-7819 .2008.00070.x

Meurman JH (2005). Probiotics: Do they have a role in oral medicine and dentistry? Eur $\mathcal{F}$ Oral Sci, 113(3): 188-196. https://doi.org/ 10.1111/j.1600-0722.2005.00191.x

Mohammed KS (2013). Antibacterial activity of Allium Sativum (Garlic) and identification of active compound by GC-MS analysis. Int $\mathcal{F}$ Pharm Bio Sci, 4(4): 1071-1076.

Mozirandi W, Tagwireyi D, Mukanganyama S (2019). Evaluation of antimicrobial activity of chondrillasterol isolated from Vernonia adoensis (Asteraceae). BMC Complement Altern Med, 19(1): 249. https://doi.org/10 .1186/s12906-019-2657-7
Obafemi TO, Akinmoladun AC, Olaleye MT, Agboade SO, Onasanya AA (2017a). Antidiabetic potential of methanolic and flavonoid-rich leaf extracts of Synsepalum dulcificum in type 2 diabetic rats. $\mathcal{F}$ Ayurveda Integr Med, 8(4): 238-246. https://doi.org/10.1016/j.jaim.2017.01.008

Obafemi TO, Akinmoladun AC, Olaleye MT, Onasanya A, Komolafe KC, Falode JA et al. (2017b). High performance liquid chromatography (HPLC) fingerprinting, mineral composition and in vitro antioxidant activity of methanol leaf extract of Synsepalum dulcificum (Sapotaceae). F Appl Pharm Sci, 7(11): 110-118. https://doi.org/10.7324/JAPS.2017.71117

Ragasa CY, Cornelio K, Bauca T, Chua S, Shen CC (2015). Chemical constituents of the leaves, stems, and fruits of Synsepalum dulcificum. Chem Nat Compd, 51(3): 588589. https://doi.org/10.1007/s10600-015 $-1356-y$

Ranasinghe P, Perera S, Gunatilake M, Abeywardene E, Gunapala N, Premakumara S et al. (2012). Effects of Cinnamomum zeylanicum (Ceylon cinnamon) on blood glucose and lipids in a diabetic and healthy rat model. Pharmacognosy Res, 4(2): 73-79. https:/doi .org/10.4103/0974-8490.94719

Saleem HG, Seers CA, Sabri AN, Reynolds EC (2016). Dental plaque bacteria with reduced susceptibility to chlorhexidine are multidrug resistant. BMC Microbiol, 16: 214. https://doi.org/10.1186/s12866-016 $-0833-1$

Saltveit ME (2017). Synthesis and metabolism of phenolic compounds. In: Yahia EM (ed.), Fruit and Vegetable Phytochemicals: Chemistry and Human Health, 2nd edn. New York: John Wiley \& Sons. https://doi .org/10.1002/9781119158042.ch5 
Seong J, Oyong GG, Cabrera EC (2018). Synsepalum dulcificum extracts exhibit cytotoxic activity on human colorectal cancer cells and upregulate $c$-fos and $c-j u n$ early apoptotic gene expression. Asian Pac f Trop Biomed, 8(3): 173-178. https://doi .org/10.4103/2221-1691.227999
Wasoh H, Tajuddin S, Halim M, Mohd-Hairul AR, Sobri MZM, Lajis AFB, Yusof MT et al. (2017). Antibacterial activity of Synsepalum dulcificum leaf extract against Listeria monocytogenes and its comparison with Strobilanthes crispus and Morus alba. f Bio-Sci, 25: 73-75. 